KS. GRZEGORZ LESZCZYŃSKI

Wydział Prawa Kanonicznego

Uniwersytetu Kardynała Stefana Wyszyńskiego w Warszawie

\title{
WARTOŚĆ DOWODOWA CONFESSIO IUDICIALIS W ŚWIETLE MITIS IUDEX DOMINUS IESUS PAPIEŻA FRANCISZKA
}

Treść: - 1. Przyznanie sądowe. - 2. Confessio iudicialis pod rządami KPK z 1917 r. - 3. Confessio iudicialis według KPK z 1983 r. - 4. Confessio iudicialis w świetle Mitis Iudex Dominus Iesus.

Prawodawca w Kodeksie Prawa Kanonicznego z roku 1983, w sprawach o stwierdzenie nieważności małżeństwa, oddaje do dyspozycji sądów kościelnych cztery podstawowe środki dowodowe. Są nimi: oświadczenia stron, dokumenty, zeznania świadków oraz opinia biegłych. Ich moc dowodowa zależy od rodzaju sprawy czyli od motywu, który powoduje nieważność małżeństwa. W konsekwencji, istnieją sprawy, w których podstawowym środkiem dowodowym jest opinia biegłych, jak np. w sprawach dotyczących niezdolności psychicznej stron powodującej nieważność zgody małżeńskiej, w innych zaś będą nimi np. oświadczenia stron, w tym przyznanie sądowe. Umieszczenie przez Prawodawcę w Kodeksie Prawa Kanonicznego oświadczeń stron na pierwszym miejscu pośród różnych środków dowodowych jest dowodem na to, iż w ujęciu Prawodawcy stanowią one podstawowy środek dowodowy w procesach o stwierdzenie nieważności 
małżeństwa ${ }^{1}$. Wartość dowodowa oświadczeń stron, w szczególności zaś interesującej nas confessio iudicialis nabiera nowego wymiaru w świetle przepisów zawartych w Liście Apostolskim Ojca Świętego Franciszka Mitis Iudex Dominus Iesus, obowiązujących od 8 grudnia $2015 \mathrm{r}^{2}$. Jaka jest zatem rzeczywista wartość dowodowa confessio iudicialis w obecnie obowiązującej procedurze stwierdzenia nieważności małżeństwa? Odpowiedź na to pytanie stanie się głównym celem niniejszego artykułu.

\section{Przyznanie sądowe}

Confessio czyli przyznanie jest to stwierdzenie jakiegoś faktu, na piśmie lub ustnie, dokonane przeciwko sobie przez którąś ze stron co do samego przedmiotu sprawy. Zatem, elementem charakteryzującym confessio jest tzw. animus confitendi, czyli świadomość dążenia do ukazania prawdy nawet za ceną pogorszenia swojej pozycji w procesie. Aktualnie obowiązujący Kodeks Prawa Kanonicznego rozróżnia dwie formy confessio: confessio iudicialis czyli przyznanie się dokonane wobec sędziego (kan. $1536 \mathrm{KPK}$ ) oraz confessio extraiudicialis czyli przyznanie się dokonane w sądzie, jednak wobec osoby trzeciej (kan. 1537 KPK).

Confessio iudicialis wchodzi w skład środka dowodowego, określanego przez Prawodawcę jako oświadczenia stron. Oświadczenia te, bowiem, mogą przybierać w procesie cztery różne formy. Są to: oświadczenia złożone w czasie przesłuchania stron; oświadczenia złożone w czasie trwania procesu, ale poza przesłuchaniem stron; oświadczenia złożone przed rozpoczęciem procesu oraz przysięga złożona przez strony procesowe. Każda z tych form oświadczeń stron

\footnotetext{
${ }^{1}$ Por. G. Leszczyński, Oświadczenia stron jako środek dowodowy w procesie o stwierdzenie nieważności małżeństwa, Prawo Kanoniczne 43(2000) nr 1-2, s. 107-121.

${ }^{2}$ FranciszeK, List apostolski motu proprio „Mitis Iudex Dominus Iesus” reformujący kanony Kodeksu Prawa Kanonicznego dotyczące spraw o orzeczenie nieważności małżeństwa, tekst łacińsko-polski, Tarnów 2015.
} 
współuczestniczy w procesie kształtowania pewności moralnej sędziego, choć nie każda ma charakter czysto dowodowy ${ }^{3}$.

Prawodawca w kan. 1530 KPK stwierdza, że sędzia w celu dokładnego poznania prawdy winien zatroszczyć się o przesłuchanie stron ${ }^{4}$. Jest to podstawowe zadanie sędziego, do którego jest wezwany z mocy swojego urzędu. Przesłuchanie stron, jak zauważa T. Rozkrut, ma wpływ na całą rozpoczętą instrukcję dowodową. Wynika to z faktu, iż sami małżonkowie najlepiej wiedzą, jak wyglądał okres ich narzeczeństwa, w jakich okolicznościach zostało zawarte małżeństwo, jak tworzyła się ich wspólnota małżeńska i co było przyczyną rozpadu pożycia małżeńskiego ${ }^{5}$. Prawodawca w przywołanym już kan. 1530 KPK stwierdza, że sędzia dla lepszego wydobycia prawdy, zawsze może przesłuchać strony. Użyty w kanonie termin semper nie jest jednomyślnie interpretowany. M.P. Hilbert twierdzi, że termin semper oznacza, że sędzia może przesłuchać strony w każdym momencie postępowania dowodowego ${ }^{6}$. Odmienną opinię prezentuje dla przykładu J.J. García Failde, który twierdzi, iż termin semper sugeruje, że sędzia może to uczynić w każdym momencie procesu . Należy przychylić się do opinii tego ostatniego biorąc pod uwagę doniosłość i znaczenie

${ }^{3}$ Por. M.J. Arroba Conde, Diritto processuale canonico, wyd. V, Roma 2006, s. $423-424$.

${ }^{4}$ Por. kan. 1530 KPK.

${ }^{5}$ Por. T. Rozkrut, Dowody, w: Komentarz do Instrukcji procesowej Dignitas connubii, red. T. Rozkrut, Sandomierz 2007, s. 255.

${ }^{6}$ Por. M.P. Hilbert, La dichiarazione delle parti nel processo matrimoniale, Periodica 84 (1995), s. 740-741. Opinia Hilberta opiera się na kan. $171 \$ 1$ Schematu z roku 1977, który brzmiał następująco: „Quoties id utile conseat ad veritatem aptius eruendam iudex debet partes interrogare, si pars aliqua petat, vel si publice intersit ut factum aliquod extra dubium ponatur; in ceteris casibus eas interrogare potest".

${ }^{7}$ Por. J.J. García Faílde, Tratado de Derecho procesal canonico, Salamanca 2005, s. 178. Autor zauważa: „El examen orientado a estas declaraciones puede harcerse en cualquier causa y en cualquier momento del proceso; debe hacerse en cualquier causa y en cualquier momento del proceso si una parte lo pide; debe hacerse en cualquier momento del proceso aunque nadie se lo pida si se trata de probar un hecho que interesa públicamente dejar fuera de toda duda, es decir, si se trata de probar un hecho que interesa al bien publico (can. 1530)...”. 
oświadczeń stron dla wydobycia prawdy dotyczącej konkretnego małżeństwa stron ${ }^{8}$.

Oświadczenia stron złożone w czasie przesłuchania wobec sędziego przybierają formę confessio iudicialis czyli przyznania się sądowego lub oświadczeń, nie będących przyznaniem się sądowym. Confessio iudicialis czyli przyznanie się, jak już zauważono, jest to stwierdzenie jakiegoś faktu, na piśmie lub ustnie, dokonane przeciwko sobie przez którąś ze stron co do samego przedmiotu sprawy ${ }^{9}$. Oświadczenia stron, nie będące przyznaniem się sądowym to wszystkie zeznania strony złożone w czasie przesłuchania działające na korzyść jej sytuacji procesowej ${ }^{10}$. Confessio złożone podczas trwania procesu, ale poza przesłuchaniem sądowym może być składane w każdym momencie procesu. Chodzi tu o potwierdzenie lub zaprzeczenie faktów i tez zawartych w skardze powodowej w formie odpowiedzi strony powodowej i strony pozwanej na skargę powodową i formułę zawiązania sporu. Oprócz nich należy ponadto zwrócić uwagę na różnego rodzaju odpowiedzi i załączone podczas procesu pisma stron, w szczególności zaś odpowiedź strony pozwanej w przypadku braku jej zainteresowania co do uczestnictwa w procesie ${ }^{11}$. Oświadczenia stron złożone przed rozpoczęciem procesu to zarówno oświadczenia mające charakter przyznania się jak i stanowiące zarzut względem strony przeciwnej. Należy mieć tu na względzie przede wszystkim przyznanie się pozasądowe, o którym mówi kan. $1537 \mathrm{KPK}$, jak i wszelkie inne formy oświadczeń załączone przez stronę na potwierdzenie własnych sformułowanych w procesie tez, stanowiące dowód pośredni ${ }^{12}$.

\footnotetext{
${ }^{8}$ Por. G. Leszczyński, Exclusio boni fidei jako symulacja zgody małżeńskiej (kan. 1101 \$ 2 KPK), Łódź 2004, s. 195.

${ }^{9}$ Por. kan. 1535 KPK.

${ }^{10}$ Por. G. Leszczý́ski, Le dichiarazioni delle parti nelle causa matrimoniali per immaturità affettiva, Apollinaris 73(2000), s. 284-285.

${ }^{11}$ Por. M. J. Arroba Conde, Diritto..., s. 424-425.

${ }^{12}$ Por. Pontificio Consiglio per i Testi Legislativi, Dignitas connubii, Instruzione da osservarsi nei tribunali diocesani e interdiocesani nella trattazione delle cause di nullità del matrimonio, Città del Vaticano 2005, art. 181.
} 


\section{Confessio iudicialis pod rządami KPK z 1917 r.}

Kodeks Prawa Kanonicznego z 1917 r. stwierdzał, że jedyną możliwą formą oświadczeń stron, posiadającą moc dowodową w procesie spornym, jest przyznanie się sądowe czyli confessio iudicialis ${ }^{13}$. Confessio iudicialis nazywana przez niektórych autorów regina probationum, przez innych zaś probatio probatissima ${ }^{14}$ zawdzięczała swoją wyjątkową pozycję pośród różnych środków dowodowych temu, iż nikt, kto występuje w procesie jako strona nie może być zainteresowany potwierdzaniem faktów, które w rzeczywistości działają na jego niekorzyść. Stąd, zaistnienie tego rodzaju sytuacji było bardzo istotnym dowodem prawdziwości faktów przedstawionych przez stronę przeciwną. Pozostałe formy oświadczeń stron w ujęciu Codex Iuris Canonici nie posiadały żadnej mocy dowodowej. Mogły one jedynie służyć jako element wywołujący czy też prowokujący samą confessio iudicialis ${ }^{15}$. Samo zaś przesłuchanie stron czy też inne oświadczenia stron, które nie miały charakteru przyznania się, nie były traktowane jako środek dowodowy ${ }^{16}$. Wartość dowodowa confessio extraiudicialis pozostawiona została ocenie sędziego ${ }^{17}$. Sama zaś confessio iudicialis w sprawach o charakterze publicznym, do których należą również sprawy o stwierdzenie nieważności małżeństwa, nie

${ }^{13}$ Kanon 1750 CIC brzmi: „Nomine confessionis iudicialis venit assertio de aliquo facto $a b$ una parte contra se et pro adversario prolata coram iudice. Confessio iudicialis fieri potest aut oretenus aut in scriptis, et quidem sive sponte, sive iudice interrogante".

${ }^{14}$ Por. E. Graziani, Giurisprudenza della S.R. Rota in tema di valutazione delle prove, DE 18 (1940), s. 296.

${ }^{15}$ Por. F. Roberti, De processibus, t. I, Roma 1941, s. 20. Autor zauważa: [...] interrogatorium est medium quo provocatur confessio adversari”.

${ }^{16}$ Por. F. Della Rocca, Istituzioni di Diritto Processuale Canonico, Torino 1946, s. 203-204.

${ }^{17}$ Kan. 1753 CIC stwierdza: „Confessio extraiudicialis dicitur confessio ipsimet adversario aut aliis extra iudicium facta. Quae confessio facta esse potest sive scriptis sive viva voce. Iudicis est, perprnsis omnibus rerum adiunctis, aestimare quanti facienda sit vis probandi in iudicio". 
posiadała nigdy mocy dowodu pełnego ${ }^{18}$. Mogło się bowiem zdarzyć, że dobro prywatne stron zaangażowanych w proces o stwierdzenie nieważności małżeństwa było przeciwne dobru publicznemu, jakim jest i zawsze pozostanie rzeczywiste stwierdzenie, czy małżeństwo danych osób zaistniało czy też nie. W przypadku zatem niezgodności istniejącej pomiędzy interesem stron i dobrem publicznemu confessio iudicialis praktycznie pozbawiona była swojej wartości ${ }^{19}$. Dlatego też, w procesie o stwierdzenie nieważności małżeństwa, poddana była ona licznym warunkom określającym formę jej składania. I tak confessio iudicialis musiała dotyczyć określonego faktu, być złożona wobec sędziego posiadającego kompetencje występowania w procesie, być złożona przez osobę posiadającą zdolność in iudicio agere, być złożona w sposób wyraźny, ustnie lub na piśmie, być dokonana w sposób wolny i świadomy oraz zawierać w sobie animus confitendi w odniesieniu do faktów działających na niekorzyść osoby składającej oświadczenie ${ }^{20}$.

Okres bezpośrednio następujący po roku 1917 czyli po wydaniu Codex Iuris Canonici charakteryzował się w Jurisprudencji przede wszystkim skoncentrowaniem uwagi na confessio iudicialis złożonej contra vinculum. Właśnie ten aspekt przedmiotowy, tzn. pro czy też contra vinculum wydawał się być podstawowym w postrzeganiu samej confessio jako dowodu w procesie kanonicznym. Zasada legalis suspicio zmuszała, przede wszystkim trybunały niższych stopni, do uznania dwóch zgodnych co do treści confessio iudicialis contra vinculum jako dowodu porozumienia się stron, a w konsekwencji próby sfałszowania rzeczywistości, w celu uzyskania wyroku stwierdzającego nieważność ich małżeństwa. Rota Rzymska, co prawda nie nadawała confessio iudicialis wartości dowodu pełnego, uznawała

\footnotetext{
${ }^{18}$ Jedynym wyjątkiem były sprawy dotyczące impotencji i małżeństwa niedopełnionego definiowane przez kan. 1975 Kodeksu Prawa kanonicznego z 1917 r. W przypadku braku innych dowodów confessio iudicialis stanowiła dowód pełny pod warunkiem przedstawienia tzw. testes septimae manus, potwierdzających wiarygodność zeznań strony.

${ }^{19}$ Por. E. Graziani, Giurisprudenza..., s. 297.

${ }^{20}$ Por. F. Roberti, De processibus..., s. 34-35.
} 
jednak jej wartość dowodową, co więcej określała ją jako fundament dowodzenia $\mathrm{w}$ sprawach prowadzonych $\mathrm{z}$ tytułu symulacji, pozostawiając decyzję co jej wartości dowodowej samemu sędziemu ${ }^{21}$.

Należy zauważyć, że w okresie poprzedzającym wydanie nowego Kodeksu Prawa Kanonicznego orzecznictwo uznawało wartość dowodową confessio iudicialis, nazywając ją nawet fundamentem, czy początkiem dowodzenia ${ }^{22}$, o wiele większe jednak znaczenie dowodowe przyznawała przyznaniu się pozasądowemu, zwłaszcza jeśli było ono dokonane w okresie poprzedzającym zawarcie przez kontrahenta związku małżeńskiego, czy też kiedy strona nie miała jeszcze w zamyśle wnieść sprawę o stwierdzenie nieważności małżeństwa ${ }^{23}$.

\section{Confessio iudicialis według KPK z 1983 r.}

Proces reformy kan. 1750 Kodeksu z 1917 r., dokonany przez Papieską Komisję przygotowującą nowy Kodeks Prawa Kanonicznego ${ }^{24}$, doprowadził do nowego określenia wartości dowodowej oświadczeń stron, w tym przyznania się sądowego. Prawodawca w kan. 1530 KPK stwierdza, że sędzia dla lepszego wydobycia prawdy, zawsze może przesłuchać strony. Co więcej, jak zauważa kanon sędzia powinien przesłuchać strony na ich żądanie lub dla udowodnienia faktu, który ze względu na interes publiczny wymaga usunięcia wątpliwości. $\mathrm{W}$ procesie kanonicznym do sędziego należy przede wszystkim dążenie do wykrycia prawdy w konkretnym przypadku. W sprawach o charakterze publicznym, do których należą sprawy o stwierdzenie nieważności małżeństwa, jest obowiązkiem sędziego przeprowadzić przesłuchanie stron, nawet jeśli strony same o to nie proszą. W tego typu sprawach do niego należy też przyjęcie przysięgi składanej przez strony, o ile tylko nie istnieje niebezpieczeństwo krzywoprzysięstwa,

\footnotetext{
${ }^{21}$ Por. E. Graziani, Giurisprudenza..., s. 298.

${ }^{22}$ Por. Sent. coram Bejan z 23.04.1969 r., RRD 61, 1969, s. 397; sent. coram Serrano z 14.07.1978 r., RRD 70, 1978, s. 385.

${ }^{23}$ Por. Sent. coram Pinto z 9.04.1973 r., RRD 65, 1973, s. 360; sent. coram Palazzini z 6.06.1973 r., RRD 65, 1973, s. 478; sent. coram Pompedda z 19.12.1970 r., RRD 62, 1970, s. 1190.

${ }^{24}$ Por. G. Leszczyński, Oświadczenia stron..., s. 113-116.
} 
co zresztą sam musi ocenić. Pomimo, że przysięga jako taka nie jest środkiem dowodowym wzmacnia bez wątpienia wiarygodność oświadczenia strony. Poza tym, sędzia w trakcie przesłuchania może doprowadzić do confessio iudicialis i do niego należy przyjęcie oraz uznanie jako dowodu confessio extraiudicialis.

W odniesieniu do stron prywatnych, kan. $1530 \mathrm{KPK}$ przyznaje każdej ze stron prawo domagania się przesłuchania w procesie strony przeciwnej. Ta z kolei, o ile tylko jest przesłuchiwana w sposób zgodny z prawem ${ }^{25}$, ma obowiązek złożenia prawdziwych zeznań (por. kan. $1531 \mathrm{KPK})^{26}$. Mówi się w tym miejscu o obowiązku, którego podstawy w odniesieniu do strony powodowej i pozwanej mają odmienny charakter. Jeśli idzie o stronę powodową, jest rzeczą zrozumiałą, że strona która wystąpiła z prośbą o rozpoczęcie procesu przyjęła na siebie zobowiązanie współpracy z trybunałem w celu dążenia do wykrycia prawdy. W odniesieniu zaś do strony pozwanej obowiązek złożenia prawdziwych zeznań wynika z konieczności uznania prawnej władzy sędziego co do wydania wyroku w sprawach określonych przez prawo kanoniczne. Warto w tym miejscu zauważyć, że odmowa złożenia zeznań przez stronę pozwaną nie może być traktowana po prostu jako przyznanie się czy też przyjęcie jakiegoś faktu jako prawdziwy. Jest zadaniem sędziego określenie motywów odmowy złożenia zeznań, a następnie wydanie właściwej oceny wspomnianego faktu. Tychże motywów może być bardzo wiele i wcale nie muszą one być związane jednoznacznie z przedmiotem sprawy. Mogą one bowiem dotyczyć charakteru osoby czy chociażby braku zainteresowania sprawą ${ }^{27}$. Warto jednak zauważyć, że brak zaangażowania ze strony pozwanej, jakkolwiek utrudnia postępowanie dowodowe, nie czyni go niemożliwym. Jak czytamy w sentencji coram Giannecchini z 19 listopada

\footnotetext{
${ }^{25}$ Zgodność z prawem przesłuchania dotyczy osoby dokonującej przesłuchania (musi to być uprawniona do tego osoba), osoby przesłuchiwanej (musi posiadać tzw. zdolność procesową) oraz sposobu i zawartości pytań w odniesieniu do przedmiotu sprawy.

${ }^{26}$ Por. kan. 1531 KPK; C. Gullo, Prassi processuale nelle cause canoniche di nullità del matrimonio, Città del Vaticano 2001, s. 134.

${ }^{27}$ Por. M. P. Hilbert, La dichiarazione..., s. 742-745.
} 
1982 r. $^{28}$, czy wcześniejszej coram Ewers z 14 października 1972 r., pomocna w tym względzie będzie dokładna analiza faktów, zestawiona $\mathrm{z}$ charakterem osobowości symulanta ${ }^{29}$.

Wartość dowodowa oświadczeń stron została zdefiniowana przez aktualnie obowiązujący Kodeks Prawa Kanonicznego w kan. 1536, 1537 i $1679^{30}$. Prawodawca w kan. 1536 stwierdza, że przyznanie się sądowe jednej strony, jeżeli chodzi o jakąś sprawę prywatną i nie dotyczy ona dobra publicznego, zwalnia pozostałe strony od obowiązku dowodzenia. W sprawach zaś dotyczących dobra publicznego, przyznanie się sądowe i oświadczenia stron, które nie stanowią przyznania się, mogą mieć moc dowodową, którą winien ocenić sędzia, uwzględniając pozostałe okoliczności sprawy, ale nie może im przyznać mocy pełnego dowodu, chyba że, jak czytamy również w sentencji coram Funghini z 14 maja 1995 r. $^{31}$, dochodzą inne elementy, które je ostatecznie wzmacniają ${ }^{32}$.

Drugi paragraf wspomnianego kanonu, dotyczący spraw o charakterze publicznym, dokonuje bardzo ważnego rozróżnienia pomiędzy przyznaniem się sądowym oraz innymi formami oświadczeń stron. Samo rozróżnienie nie jest bez wątpienia nowością wprowadzoną przez Kodeks z 1983 r.. Nowością natomiast jest postawienie na tym

\footnotetext{
${ }^{28}$ Por. Sent. coram Giannecchini z 19.11.1982 r., RRD 74, 1983, s. 539.

${ }^{29}$ Por. Sent. coram Ewers z 14.10.1972 r., RRD 64, 1972, s. 539-540. Czytamy tutaj: „Reapse difficultas adest probandi animum simulandi, ubi desunt declarationes explicitae sive iudiciales sive extraiudiciales. Attamen, potiusquam ad verba, ad facta univoca et certe probata iudex in eiusmodi causis oportet attendat. Ceterum, potissimum ad evincendam simulationem admittuntur indicia, coniecturae et praesumptiones: immo, deficiente directa probatione, cumque agatur de actu interno, asserta simulatio probari valet nonnisi praesumptionibus. Quae hunc in fidem ducuntur e circumstantiis matrimonium antecedentibus, concomitantibus et subsequentibus. Pressius vero, pro excluso bono fidei praesumptio conicitur ex indole contrahentis qui sit effrenatae libidinis atque nullius legis iugi patiens".

${ }^{30}$ Warto w tym miejscu zauważyć, że oświadczenia stron złożone pod wpływem przymusu i ciężkiej bojaźni, jak i zawierające błąd faktyczny, w myśl kan. 1538 KPK, pozbawione są jakiejkolwiek mocy dowodowej (por. również kan. 125 i 126 KPK).

${ }^{31}$ Por. Sent. coram Funghini z 24.05.1995 r., RRD 87, 1995, s. 316.

${ }^{32}$ Por. kan. 1536 KPK.
} 
samym poziomie, przynajmniej teoretycznie, przyznania się sq̨owego oraz innych form oświadczeń stron, które nie stanowią przyznania się. Wszystkie bowiem one posiadają, w myśl kan. 1536 KPK, moc dowodową, której wartość winna być określona w konkretnym przypadku przez sędziego. On też w ocenie wartości dowodowej poszczególnych oświadczeń stron winien wziąć pod uwagę wszystkie inne okoliczności sprawy jak i inne środki dowodowe, takie jak zeznania świadków, opinie biegłych czy wreszcie istniejące dokumenty. Warto jednak zauważyć, że norma kan. 1536 KPK nie stwierdza, że wszystkie formy oświadczeń stron muszą posiadać tę samą moc dowodową. Decyzję co do ich wartości pozostawia ona sędziemu. W związku z tym, jest możliwa sytuacja, w której przyznanie się sądowe będzie stanowić najbardziej przekonujący dowód dla sędziego ${ }^{33}$.

\section{Confessio iudicialis w świetle Mitis Iudex Dominus Iesus}

Przepisy zawarte w Mitis Iudex Dominus Iesus Ojca Świętego Franciszka nie zmieniają rozumienia środka dowodowego, jakim jest confessio iudicialis, ani też nie dokonują zmian co do jej stosowania $\mathrm{w}$ aspekcie proceduralnym. Wprowadzają natomiast istotną zmianę co jej wartości dowodowej w procesie o stwierdzenie nieważności małżeństwa czy, jak określa to T. Rozkrut, uściślają walor dowodowy sądowego przyznania się i oświadczeń stron procesowych ${ }^{34}$. Zgodnie, bowiem, z kan. $1678 \$ 1$ Mitis Iudex Dominus Iesus w sprawach o nieważność małżeństwa przyznanie się sądowe oraz oświadczenia stron, poparte ewentualnymi zeznaniami świadków potwierdzającymi ich wiarygodność, mogą mieć pełną wartość dowodową, którą winien ocenić sędzia, po dokładnym rozważeniu wszystkich wskazówek i poszlak, chyba że pojawiają się inne elementy, które je obalają.

Należy zatem zauważyć, że zarówno przyznanie się sądowe, jak i inne oświadczenia stron mogą mieć wartość dowodu pełnego.

\footnotetext{
${ }^{33}$ Por. C. Tricerri, Commento al codice di diritto canonico, Roma 1983, s. 959.

${ }^{34}$ T. Rozkrut, Wprowadzenie i instrukcja sprawy, w: Praktyczny komentarz do Listu apostolskiego motu proprio Mitis Iudex Dominus Iesus papieża Franciszka, Tarnów 2015, s. 107.
} 
Z oczywistych względów wartość dowodowa przyznania się sądowego w niektórych typach spraw o stwierdzenie nieważności małżeństwa będzie wyższa niż innych oświadczeń stron, jak choćby w sprawach prowadzonych $\mathrm{z}$ tytułów różnych form symulacji. W innych pozostałe formy oświadczeń stron mogą mieć również wartość dowodu pełnego.

Interesujące nas bezpośrednio przyznanie się sądowe, w świetle kan. 1536 KPK, mogło uzyskać moc dowodu pełnego jeśli potwierdzały je lub wzmacniały inne elementy. Stąd pomimo, iż przyznanie się sądowe posiadało przyznaną przez Prawodawcę wartość dowodową, jej ocena musiała mieć charakter relatywny w odniesieniu do innych elementów, które mogły je wzmocnić lub osłabićs ${ }^{35}$. Wypada zatem w tym miejscu zadać sobie pytanie: co kryje się pod terminem inne elementy użytym przez kan. 1536 KPK? Wyjaśnienie terminu inne elementy nie jest $\mathrm{z}$ pewnością zadaniem łatwym ze względu na bardzo różnorodną jego interpretację w opinii poszczególnych autorów. Z pewnością termin ten nie oznacza „inne dowody”, ponieważ jeśli tak to cały charakter nowatorski kan. 1536 KPK straciłby na wartości. Morrisey, dla przykładu, pod pojęciem „inne elementy” rozumie uwarunkowania rodzinne i społeczne jak też wpływ kultury, religii i polityki na osobowość danego człowieka ${ }^{36}$. Inni na przykład jako element wzmacniający wiarygodność oświadczeń stron uznają fakt, iż w niektórych krajach wyrok stwierdzający nieważność małżeństwa nie posiada, w myśl prawa cywilnego, skutków cywilnych ${ }^{37}$. W każdym razie nie istnieje jedyna opinia co do rozumienia terminu „inne elementy” użytego w kan. 1536 KPK.

W tym miejscu pomocą dla rozumienia terminu „inne elementy” może być norma zawarta w kan. 1679 KPK, który stwierdza, że „Jeśli nie ma skądinąd pełnych dowodów, sędzia, dla oceny zeznań stron według przepisu kan. 1536, powinien się posłużyć, jeżeli to możliwe,

\footnotetext{
${ }^{35}$ Por. G. Leszczyński, Dichiarazioni..., s. 297.

${ }^{36}$ Por. F. G. Morrisey, L'interrogation des parties dans le causes de nullitè du mariage, w: Dilexit Iustitiam, Città del Vaticano 1984, s. 363-364.

${ }^{37}$ Por. M. F. Pompedda, Il valore probativo delle dichiarazioni delle parti nella nuova giurisprudenza della Rota Romana, IE 5(1993), s. 449.
} 
świadkami co do prawdomówności samych stron, oprócz innych poszlak i wskazówek”. Wydaje się, że Kodeks używając pojęcia testes credibilitate ma na względzie osoby, które ze względu na szczególny przykład moralności czy też pozycję, którą zajmują we wspólnocie Kościoła (duchowni, osoby konsekrowane) mogą zaświadczyć o prawdomówności samych stron. Jest rzeczą zrozumiałą, że osoba taka winna na tyle znać strony, czy jedną z nich, aby móc z czystym sumieniem zaświadczyć o ich prawdomówności. I choć argument ten ma charakter bardziej moralny niż prawny, wydaje się być istotny szczególnie w sprawach, w których przyznanie się sądowe lub inne oświadczenia stron stanowią podstawowy środek dowodowy. Warto w tym miejscu zauważyć, że kan. 1679 KPK używa określenia si fieri potest, w związku z tym odwołanie się przez sędziego do tzw. testes credibilitate nie ma charakteru absolutnego i dlatego możliwa jest sytuacja, w której sędzia mógłby nadać oświadczeniom stron moc dowodu pełnego bez odwołania się do świadków prawdziwości ich zeznań, o ile tylko zeznania te byłyby wzmocnione innymi poszlakami czy wskazówkami.

W świetle Mitis Iudex Dominus Iesus zeznania świadków potwierdzających wiarygodność strony powodowej lub pozwanej nabiera zupełnie nowego wymiaru. Potwierdzenie, bowiem, wiarygodności strony przez zeznających w procesie świadków jest elementem wystarczającym do nadania przyznaniu się sądowemu lub innemu oświadczeniu strony mocy dowodu pełnego. Co więcej, jak zauważa J. Krajczyński, sędzia może podważyć wartość dowodową oświadczeń i przyznania się sądowego tylko wtedy, gdy w aktach sprawy znajdzie przynajmniej jedną racjonalną przesłankę, która wskazuje na brak wiarygodności stron ${ }^{38}$. Istotna rola przyznana przez Prawodawcę zeznaniom świadków stawiają przed sędzią konieczność rzetelnej oceny wiarygodności samych świadków. W tym względzie, jak się wydaje, sędzia dokonując oceny merytorycznej zeznań świadków, winien też ocenić ich wiarygodność czyli stan osoby i jej uczciwość.

\footnotetext{
${ }^{38}$ Por. J. KrajCzyński, Proces zwyczajny, w: Proces małżeński według motu proprio Mitis Iudex Dominus Iesus, Płock 2015, s. 71.
} 
Dlatego też Prawodawca w kan. 1572 KPK przewiduje możliwość zażądania przez sędziego świadectwa kwalifikacyjnego. Zdaniem J. J. García Failde, takowe świadectwo może pomóc sędziemu w poznaniu sposobu życia, jak zaangażowania religijnego świadka, co może mieć znaczenie $\mathrm{w}$ odniesieniu do obowiązku mówienia prawdy w procesie kościelnym. Ten sam autor jednak podkreśla, że nie należy przeceniać relacji zachodzącej między stylem życia, a mówieniem prawdy, gdyż relacja ta nie zawsze jest jednoznaczna ${ }^{39}$. Zdarzają się bowiem świadkowie, którzy pomimo dobrej opinii zeznają nieprawdę zeznając w przeświadczeniu konieczności udzielenia pomocy stronie, niezależnie od prawdy faktycznej ${ }^{40}$. Nie można też wykluczyć, że zeznania świadków są ukształtowane przez same strony, którym zależy na potwierdzeniu przedstawionych przez nie te ${ }^{41}$.

Wartość dowodowa przyznania się sądowego podlega oczywiście ocenie sędziego, który winien zestawić zawarte $\mathrm{w}$ nim fakty z innymi faktami i poszlakami. W ocenie oświadczeń stron, sędzia winien przede wszystkim ocenić jaki jest stan osoby składającej oświadczenie, $w$ tym przyznającej się do popełnienia czynu lub np. istniejącego u niej zaburzenia psychicznego i jaka jest jej uczciwość. Dokonując oceny oświadczeń stron sędzia winien zwrócić szczególną uwagę na stan, w jakim znajduje się aktualnie, osoba składająca zeznania, jeśli jest nią osoba cierpiąca na jakąś chorobę czy zaburzenie sfery psychicznej lub emocjonalnej. Jest to istotne dla oceny jej wiarygodności w odniesieniu do zdolności poznania, zapamiętania i przedstawienia własnej historii.

${ }^{39}$ Por. J.J. García Failde, Nuevo derecho procesal canonico, Salamanca 1984, s. 140. Autor zauważa: „Ha de tenerse muy en cuenta la veracidad de la que dé muestras el testigo. Para ello es importante conocer su modo de ser, sus costumbres, su religiosidad práctica, etc. Pero no debe exagerarse hasta el extremo de establecer una correlación poco menos que necesaria entre buenas / malas costumbres, etc., y veracidad / no veracidad del testigo: personas hay que, a pesar de sus malas costumbres..., son veraces y que, no obstante sus buenas costumbres..., no son veraces".

${ }^{40}$ Por. Sent. coram De Laversin, 10.11.1992, RRD 84, 1992, s. 546.

${ }^{41}$ Por. Sent. coram Stankiewicz, 17.12.1993, RRD 85, 1993, s. 783. 
Warto w tym miejscu, dla przykładu odwołać się do kilku wyroków Roty Rzymskiej wydanych w sprawach prowadzonych z tytułu niezdolności natury psychicznej do podjęcia istotnych obowiązków małżeńskich, w których istotnym środkiem dowodowym było przyznanie się sądowe. W niektórych sprawach swoje zeznania składały, dla przykładu, osoby dotknięte stanem psychozy maniakalno-depresyjnej. W wyroku coram Civili z 19 czerwca 1996 r. znajdują się też zeznania pozwanego, który potwierdza fakt istnienia zaburzenia w chwili zawierania małżeństwa, choć jak się wydaje nie ma wiedzy co do konkretnego typu zaburzenia albo nie ma świadomości prawdy o swojej chorobie. Pozwany zeznaje bowiem, że już przed zawarciem małżeństwa wyjaśnił powódce charakter zaburzenia, na które cierpi, a które jego zdaniem jest konsekwencją nadużywania alkoholu i środków odurzających podczas służby w czasie wojny w Libanie $^{42}$. Pozwany mówi o wyczerpaniu nerwowym, choć analiza pastowanych leków wskazuje na psychozę maniakalno-depresyjną. Sam pozwany zresztą potwierdza, że był leczony za pomocą litu, podstawowego środka w leczeniu osób ze stwierdzoną psychozą maniakalno-depresyjną ${ }^{43}$.

Przyznanie się sądowe znajdujemy również w wyroku coram Boccafola z 20 kwietnia 1989 r., w którym ponens przywołuje zeznania strony pozwanej. Pozwana potwierdza zachowania maniakalne, jak i depresyjne podając jednocześnie konkretne daty poszczególnych epizodów. Jak zeznaje w 1976 roku przeszła najpierw epizod depresyjny, a następnie od grudnia tego roku epizod maniakalny ${ }^{44}$.

\footnotetext{
${ }^{42}$ Por. tamże, s. 476. Czytamy tutaj: „Ho spiegato a mia moglie la natura della mia malattia nervosa prima del matrimonio, dalla quale sono stato colpito perché bevevo troppo e facevo uso di sostanze stupefacenti durante la guerra cilive in Libano che fu la causa principale del mio esaurimento nervoso".

${ }^{43}$ Por. tamże. Czytamy dalej: „Avevo detto anche a mia moglie (semper ante nuptias) che prendevo il farmaco «Lithium», che prendo tutt'oggi, poiché il dottor D. Crede che questo farmaco impedisce una eventuale ricaduta nell'esaurimento nervoso".

${ }^{44}$ Por. Sent. coram Boccafola, 20.04.1989, RRD 81, 1989, s. 304. Pozwana zeznała: „Ho avuto una crisi depressiva nella primavera del 1976... Successivamente nel
} 
W niektórych sprawach Stroną powodową jest osoba cierpiąca na psychozę maniakalno-depresyjną. W wyroku coram Pinto z 31 maja 1985 r., ponens przywołuje zeznania powoda, który określa stan, w jakim zawierał małżeństwo jako stan depresyjny. Powód zeznaje, że $\mathrm{z}$ jednej strony odczuwał potrzebę towarzystwa $\mathrm{z}$ racji na swoją samotność i zgorzknienie, z drugiej zaś czuł się przymuszony do małżeństwa w stosunku do którego nie wykazywał żadnego entuzjazmu. Nie wyczuwał, jak zeznaje, jaka jest rzeczywista sytuacja, nie przyjmował żadnych rad, których udzielali mu przyjaciele. Czuł, że skoro związał się z pozwaną i co więcej doszło do współżycia jedyną słuszną decyzją jest zawarcie małżeństwa. Miał wrażenie, że otrzyma od niej pocieszenie i wsparcie po rozstaniu się z poprzednią dziewczyną. Jak przyznaje logika wskazywałaby na konieczność innego zachowania, on natomiast zastosował logikę ucieczki od poprzednich problemów ${ }^{45}$.

W wyroku coram Colagiovanni z 23 stycznia 1990 r., stwierdzającym iż nie udowodniono nieważności małżeństwa, zawarte są zarówno oświadczenia sądowe strony powodowej, jak i pozwanej.

dicembre del 1976 ebbi una crisi opposta di euforia... Nel momento di euforia scrissi lettere d'amore all'avvocato di mio marito e feci dei testamenti....Nell'ultimo giorno di Carnevale del 1977 andai davanti al Tribunale di Bologna con un cartello con su scritto: Montanella Agnella”.

${ }^{45}$ Por. Sent. coram Pinto, 31.05.1985, RRD 77, 1985, s. 284-285. Powód zeznał: „Mi invaghii, aveva l'età di anni quattordici e mezzo. Allora io ero frastornato, deluso, scoraggiato; mi sembrò di avere un conforto che non avevo mai avuto. Così, nel breve giro di un mese di fidanzamento... ben presto incominciarono le relazioni intime... momenti di grande dubbio ed incertezza, non mi sentivo a posto nei confronti della ragazza, tuttavia desideravo la sua compagnia, non perché, le volessi bene, ma per la mia amarezza e solitudine....Quello è stato un tempo per me di grande sofferenza, dovevo sposarmi, non ne avevo nessun entusiasmo; ero stordito e mi sembrava di non poter fare a meno di riparare e quindi non mi restava che il matrimonio; una volta separatomi dalla prima ragazza, ho perso l'equilibrio interiore, non mi sono più controllato e sono stato vittima di raggiri; non ho capito nulla sulla reale situazione in cui ero coinvolto;...preso come da un panico, non ho sentito nulla di quanto gli amici mi andavano ripetendo, sconsigliandomi di fare quel passo; ad un certo punto non ho visto altro che il momento di sposare, sperando che tutto finisse...”. 
Nie ma natomiast przyznania się sądowego, gdyż pozwana twierdzi jednoznacznie, że jej problemy chorobowe były następstwem urodzenia dziecka, a więc nie mogły istnieć w chwili zawierania przez nią małżeństwa ${ }^{46}$. Inne zdanie wyraża w tym względzie powód, który zeznaje, że jego żona cierpiała na chorobę o charakterze emocjonalnym sugerując, że były to stany maniakalne. Tak wynika z zeznań złożonych przez powoda w trakcie wstępnego przesłuchania, gdzie stwierdził, że jego żona wielokrotnie podejmowała próby samobójcze, skądinąd charakterystyczne dla stanu maniakalnego. W trakcie przesłuchania sądowego powód skorygował swoje zeznania twierdząc, ze tych prób nie było wiele. Co najważniejsze z jego zeznań wynika, że miały one miejsce dopiero po zawarciu małżeństwa ${ }^{47}$.

Podsumowując należy stwierdzić, że wartość dowodowa przyznania się sądowego określona w Mitis Iudex Dominus Iesus w zasadzie jest doprecyzowaniem przepisów zawartych w Kodeksie Prawa Kanonicznego. Jednoznacznie jednak zostaje podkreślona możliwość, w ocenie sędziego, nadania confessio iudicialis mocy dowodu pełnego po spełnieniu jednego warunku dotyczącego wiarygodności strony dokonującej przyznania. Jak wynika z przepisu kan. $1678 \$ 1$ MIDI sędzia może przyznać confessio iudicialis moc dowodu pełnego, co oznacza że nie jest do tego zobowiązany. Nie może natomiast tego uczynić jeśli inne elementy zawarte w materiale dowodowym obalają fakty zawarte w przyznaniu sądowym. Stąd zestawienie faktów i okoliczności zawartych w confessio iudicialis z innymi elementami

\footnotetext{
${ }^{46}$ Por. Sent. coram Colagiovanni, 23.01.1990, RRD 82, 1990, s. 14.

${ }^{47}$ Por. tamże, s. 14. Powód zeznał: „....Io Ann ha sofferto, a quanto pare, di depressioni maniache ed in numerose occasioni tentava di suicidarsi... Vi è stata la mancanza (difetto) della comunicazione e della compartecipazione (condivisione) come pure il difetto di sensibilità (insensibilità) negli ultimi giorni del nostro matrimonio... Non poteva dormire... era agitata (nervosa). Alcune notti lei rimaneva alzata (in piedi) fino all'alba cucendo. Quando andava a qualche ricevimento la sua personalità, normalmente estroversa, diveniva esagerata".
} 
i poszlakami sprawy jest niezwykle istotne dla uzyskania przez sędziego pewności moralnej koniecznej do wydania wyroku ${ }^{48}$.

\section{The value of confessio iudicilias in Mitis Iudex Dominus Iesus}

Taking up the value of confessio iudicialis for declaring a marriage null and voit, the author begins his reflections with a look at different forms of declarations of the parties. From the point of view of marriage validity, of special significance is also the analysis of confessio iudicialis in the Code of Canon Law from 1917 and 1983. The last part of the author's reflections is devoted to the analysis of new canon 1678 of the Code of Canon Law, declaring in Pope's Francis Mitis Iudex Dominus Iesus.

SŁOWA KLUCzowE: dowód, przyznanie, proces

KEYWORDS: proof, confession, process

\section{Nota o Autorze:}

Ks. PROF. DR HAB. GRZegorz LeSzCZyŃsKi - profesor zwyczajny na Wydziale Prawa Kanonicznego UKSW w Warszawie, kierownik katedry Kanonicznego Prawa Administracyjnego i Prawa o Dobrach Kościoła UKSW, profesor zwyczajny Uniwersytetu Łódzkiego, Oficjał Trybunału Metropolitalnego łódzkiego, członek Centralnej Komisji ds. Stopni i Tytułów Naukowych.

${ }^{48}$ T. Rozkrut, Pewność moralna niezmiennym uwarunkowaniem pozytywnego wyrokowania, w: Procesy i procedury: nowe wyzwania, red. G. Leszczyński, Warszawa 2015, s. 63. 